FIU Law Review

Spring 2015

\title{
Unmanned Aircraft Systems and Technologies: Challenges and Opportunities for States and Local Governments
}

\author{
Daniel Friedenzohn \\ Embry-Riddle Aeronautical University \\ Mike Branum \\ Naval Air Station Fort Worth, Joint Reserve Base
}

Follow this and additional works at: https://ecollections.law.fiu.edu/lawreview

Part of the Other Law Commons

Online ISSN: 2643-7759

\section{Recommended Citation}

Daniel Friedenzohn \& Mike Branum, Unmanned Aircraft Systems and Technologies: Challenges and Opportunities for States and Local Governments, 10 FIU L. Rev. 389 (2015).

DOI: https://dx.doi.org/10.25148/lawrev.10.2.7

This Article is brought to you for free and open access by eCollections. It has been accepted for inclusion in FIU Law Review by an authorized editor of eCollections. For more information, please contact lisdavis@fiu.edu. 


\title{
Unmanned Aircraft Systems and Technologies: Challenges and Opportunities for States and Local Governments
}

\author{
Daniel Friedenzohn ${ }^{*} \&$ Mike Branum $^{* *}$
}

The term unmanned aircraft system (UAS) refers to a remotely piloted aircraft, without an on-board pilot, that is operated via remote data-link transmissions and, in some cases, autonomously. Due to progressive technological advancements, UAS have become increasingly affordable in recent years, thereby bolstering their demand. As a result, the UAS industry is positioned to grow significantly during the next several decades as this technology becomes widely available for use by the private sector as well as state and local governments. In 2012, the United States Congress passed the Federal Aviation Administration (FAA) Modernization and Reform Act of 2012 (FRMA) which requires the FAA to develop a plan "for the safe integration of civil unmanned aircraft systems into the national airspace system" by September 30, 2015. ${ }^{1}$

Offering tremendous benefits to society, UAS can enhance public safety by assisting in search and rescue operations, recovery efforts from natural disasters, and assisting in documentation of crime scenes. ${ }^{2}$ UAS also have the potential to play a key role in helping to mitigate disasters with the means to check radiation levels at damaged nuclear power plants and locate missing persons following a severe hurricane or flooding event. ${ }^{3}$

Value from operating UAS can also be tied to data collection and analysis for monitoring land erosion and the illegal poaching of animals. ${ }^{4}$ Additionally, UAS offer many benefits to news media as it enables them to capture images that might not otherwise be photographed. ${ }^{5}$ Furthermore,

* J.D., M.A., Economics Associate Professor, Department of Aeronautical Science, Embry-Riddle Aeronautical University.

** Community Planning Liaison Officer, Department of the Navy, Naval Air Station Fort Worth, Joint Reserve Base. The views presented are those of the author(s) and do not necessarily represent the views of the Department of Defense or its components.

1 FAA Modernization and Reform Act of 2012 (FMRA), Pub. L. No. 112-95, § 332, 126 Stat. 72 (2012).

2 The Benefits of Unmanned Aircraft Systems: Saving Time, Saving Money, Saving Lives, Ass'N FOR UNMANNED VeHICLE SYSTEMS INT'L, https://epic.org/events/UAS-Uses-Saving-Time-SavingMoney-Saving-Lives.pdf (last visited Jan. 8, 2015).

3 Id.

$4 \quad I d$.

5 See Nabiha Syed \& Michael Berry, Journo-Drones: A Flight Over the Legal Landscape, 30 COMM. LAW. 23 (2014). 
UAS operational costs are much lower in comparison to manned, fixed-wing aircraft and helicopters. ${ }^{6}$

With additional benefits to agriculture, the environment, and scientific research, the importance of UAS to society is significant and largely untapped in the absence of a broader FAA rule permitting their use by society. In fact, the demand for UAS by civilian and commercial entities will grow during the next ten years. ${ }^{7}$ Lucintel, a global research firm, estimates that the civilian market for UAS will be valued at over $\$ 7$ billion during the next decade. ${ }^{8}$

While the FAA prepares to enact UAS regulations, many state and local governments have taken action to put laws in place which affect this emerging sector in the aviation industry. Furthermore, states have also undertaken steps to enact laws specifically regulating certain types of activities undertaken by UAS as well imposing certain restrictions on who may engage in those UAS activities. During the 2013 state legislative sessions, forty-three states considered ninety-six bills. ${ }^{9}$ Nine of these states moved forward with enacting legislation. ${ }^{10}$

This article is intended to address legal and planning issues related to the introduction of UAS in the national airspace via the prism of three levels of government. Part one will provide an overview of the federal government's role in regulating aviation activity. Part two will provide an overview of Texas's attempt to protect privacy rights while also supporting the use of UAS in the State. Part three will examine Idaho's UAS statute and the importance of UAS for agriculture in the State. Part four will discuss attempts by local governments to enact ordinances and pass resolutions with respect to UAS. Part five will conclude with an analysis of why it is important for states and municipalities to lead in the development of laws and policies with respect to local-level planning and integration of UAS activity.

\section{THE FEDERAL GOVERNMENT'S ROLE IN REgUlATING AVIATION ACTIVITY}

Concern about the operation of UAS in the United States has resulted in many state and local governments enacting statutes or ordinances that restrict

\footnotetext{
$6 \quad I d$.

7 S.J. Zaloga, D.D. Rockwell, \& F. Philip, World Unmanned Aerial Vehicle Systems MARKET PROFILE AND FORECAST 16 (2013).

8 U.S. Dept. of Transp., Unmanned Aircraft System (UAS) SERVice Demand 2015-2035: LiteratURE REVIEW AND PROJECTIONS OF FUTURE USAGE 94 (2013).

9 A. Bohm, The Year of the Drone: An Analysis of State Legislation Pass, AM. CIV. LiBeRTIES UNION (Nov. 7, 2013), https://www.aclu.org/blog/technology-and-liberty/year-drone-rounduplegislation-passed-year.

10 A. Bohm, Status of Domestic Drone Legislation in the States, AM. Civ. LiberTiEs UnION (Jan. 22, 2014), https://www.aclu.org/blog/technology-and-liberty/status-domestic-drone-legislation-states.
} 
the use of these systems in their jurisdictions. Privacy advocates have articulated concerns about the type of surveillance technology that UAS users may improperly transport that could result in the violation of constitutional as well as common law and statutory privacy rights. ${ }^{11}$ Although the FAA has released a Notice of Proposed Rulemaking (NPRM) for the Operation and Certification of Small Unmanned Aircraft Systems, a Government Accountability Office report to the House of Representatives indicates the FAA plans to issue a final rule approximately sixteen months after releasing its small UAS NPRM. ${ }^{12}$

The United States government has broad and, in some situations, exclusive authority to regulate many aspects of aviation. The Federal Aviation Act states in part that the federal government has "exclusive sovereignty of airspace of the United States." 13 The Federal Aviation Administration (FAA) also has authority to "develop plans and policy for the use of the navigable airspace and assign by regulation or order the use of the airspace necessary to ensure the safety of aircraft and the efficient use of airspace." 14 The FAA also has the authority to "modify or revoke an assignment when required in the public interest." 15 Other federal agencies such as the National Telecommunications and Information Administration (NTIA) and the Federal Communications Commission (FCC) also impact aviation. For instance, UAS operators must utilize existing spectrums of frequency approved for public use or have the appropriate FAA and NTIA "approval to transmit on the radio frequencies (RF) used for UAS uplink and downlink of control, telemetry, and payload information." 16

In City of Burbank v. Lockheed Air Terminal, Inc, the U.S. Supreme Court reviewed a challenge of the City of Burbank's ordinance, which imposed a curfew on flights operated by jet aircraft between 11:00 p.m. and 7:00 a.m. at the Hollywood-Burbank Airport. ${ }^{17}$ Appellee Lockheed Air Terminal, Inc. argued, in part, that the City of Burbank's ordinance was

11 Field Forum on the Impact of Domestic Use of Drone Technology on Privacy and Constitutional Rights of All Americans, Before the H. Subcomm. on Crime, Terrorism and Homeland Security of the H. Comm. on the Judiciary, 112th Cong. 2-9 (2012) (statement of Amie Stepanovich, Associate Litigation Counsel, Electronic Privacy Information Center).

12 Operation and Certification of Small Unmanned Aircraft Systems, _ Fed. Reg. _ (proposed Feb. 15, 2015) (to be codified at 14 C.F.R. Parts $21,43,45,47,61,91,101, \overline{107}$ and 183); U.S. Gov'T ACCOUNTABILITy OfFice, GAO-15-254T, UnMANNED AERIAL Systems: EFForTs MADE TOWARD INTEGRATION INTO THE NATIONAL AIRSPACE CONTINUE, BUt MANY ACTIONS STILL REQUIRED (2014).

1349 U.S.C. § 40103(a)(1) (1982); see John Villasenor, Observations from Above: Unmanned Aircraft Systems and Privacy, 36 HARVARD J. L. \& PUB. POL'Y 457, 513 (2013).

1449 U.S.C. $\$ 40103(b)(1)$.

15 Id.

16 Fed. Aviation Administration, N 8900.227, Unmanned Aircraft Systems (UAS) OPERATIONAL APPROVAL (2013).

17 City of Burbank v. Lockheed Air Terminal, Inc., 411 U.S. 624 (1973). The City of Burbank enacted a series of ordinances to eliminate noise from jet aircraft during late night hours. 
preempted by the Federal Aviation Act, as amended by the Noise Control Act of $1972 .{ }^{18}$ In analyzing the preemption issue on appeal, the high court quoted Justice Jackson's opinion in Northwest Airlines, Inc. v. Minnesota ${ }^{19}$ which stated:

Federal control is intensive and exclusive. Planes do not wander about in the sky like vagrant clouds. They move only by federal permission, subject to federal inspection, in the hands of federally certified personnel and under an intricate system of federal commands. The moment a ship taxis onto a runway it is caught up in an elaborate and detailed system of controls. ${ }^{20}$

The Court in City of Burbank ruled against the local government's ordinance, and held that both the Federal Aviation Administration and the Environmental Protection Agency "had full control over aircraft noise, which therefore preempted state and local control.,"21

Subsequent court decisions have also reaffirmed the broad and exclusive reach of the federal government in regulating many aspects of aviation. In Montalvo v. Spirit Airlines, the Ninth Circuit U.S. Court of Appeals stated that "[ $\mathrm{t}] \mathrm{he}$ FAA and regulations promulgated pursuant to it establish complete and thorough safety standards for air travel, which are not subject to supplementation by, or variation among, state laws." 22 Courts have also ruled that because many areas related to airline service, often referred to as passenger protections, fall under the category of airline safety, only the federal government has the right to regulate this arena. ${ }^{23}$

The federal government's ability to regulate aviation-related activity, however, is not exclusive. For example, in Santa Monica Airport Association v. City of Santa Monica, the Ninth Circuit Court of Appeals was asked to rule on whether federal law preempted the City's ordinances regulating aircraft operations, including a night curfew on aircraft operations as well as a ban on helicopter training. ${ }^{24}$ The Court of Appeals, in holding that the local government's ordinance were not preempted by federal regulation, agreed with the lower court's finding that the ordinances neither regulated airspace nor flight. ${ }^{25}$

$I d$.

19322 U.S. 292, 303 (1944).

20 City of Burbank, 411 U.S. at 633-34 (citing Northwest Airlines, 322 U.S. at 303 (internal citations omitted)).

21 Id. at 633-40.

22 Montalvo v. Spirit Airlines, 508 F.3d 464, 468 (2007).

23 See, e.g., Air Transport Ass'n of Am., Inc. v. Cuomo, 520 F.3d 218, 224-25 (2d Cir. 2008).

24 Santa Monica Airport Ass'n v. City of Santa Monica, 659 F.2d 100 (9th Cir. 1981).

25 Id. at 105. 
Similarly, in other types of cases, courts have ruled that state law was not preempted by the Federal Aviation Act and other laws such as the Airline Deregulation Act. In Goodspeed Airport, LLC v. East Haddam Inland Wetlands \& Watercourses Commission, the private airport owner sought to cut down trees on a portion of the property, which included wetlands. ${ }^{26}$ The airport argued that since the "trees qualify as obstructions, they are therefore hazards to air navigation under the FAA Regulations and the otherwise applicable state and local statutory and regulatory framework." ${ }^{27}$ The airport claimed that state and local laws imposing certain requirements that it had to adhere to before it cut down the trees were preempted by the Federal Aviation Act and regulations enacted pursuant to that law. ${ }^{28}$

The U.S. Court of Appeals for the Second Circuit joined other circuits in ruling "that Congress intended to occupy the field of air safety." ${ }^{29}$ The court, however, held that "the generally applicable state laws and regulations imposing permit requirements on land use challenged [there] [did] not, on the facts before [the court], invade that preempted field." ${ }^{30}$

These decisions show that there are certain areas, however limited, where state and local governments may have the legal authority to enact laws impacting aviation activities, including those pertaining to UAS operations. States and local governments are currently examining what role UAS technology can play for law enforcement and other governmental needs. At the same time, states are, or, in some cases, have explored their role in, ensuring that the privacy rights of their citizens are protected.

\section{Attempts by States to Regulate UAS: The TeXas PRIVACy ACt}

In general, states and local governments have broad powers to establish law enforcement agencies and, subject to federal and state constitutional standards, regulate law enforcement activities. ${ }^{31}$ This power includes the authority to regulate what vehicles law enforcement agencies utilize. Accordingly, several states, including Florida and Virginia, have enacted statutes that restrict or prohibit the use of UAS by a state or local law enforcement agency.

26 Goodspeed Airport LLC v. E. Haddam Inland Wetlands \& Watercourses Comm'n, 634 F.3d 206, 207 (2d Cir. 2011).

27 Id. at 209.

28 Id.

29 Id. at 210.

30 Id. at 212.

31 John S. Baker, State Police Powers and the Federalization of Local Crime, 72 TEMPLE L. REV. 673, 691 (1999). See Garcia v. United States, 469 U.S. 70, 89 (1984) (Stevens, J., dissenting) ("Law enforcement remains, and should remain, the primary responsibility of the several States. Every increase in the power of the federal prosecutor moves us a step closer to a national police force.”). 
In 2013, Virginia became the first state in the union to enact a law that prohibits, with some narrowly tailored exceptions, state or local law enforcement agencies from operating a UAS before July $1,2015 .{ }^{32}$ Florida passed a law in 2013, which also restricts the use of UAS by law enforcement agencies. ${ }^{33}$ The Florida law, however, does allow law enforcement agencies to operate a UAS if they have obtained a signed warrant from a judge. ${ }^{34}$ States such Indiana and Montana have also followed the same path in restricting UAS operations by law enforcement agencies. ${ }^{35}$

Some states, however, have expanded the reach of their legislative authority by enacting statutes which regulate the use of UAS by private individuals or entities. The Texas Privacy Act (TPA), which went into effect in September 2013, also imposes certain restrictions on the use of UAS by law enforcement agencies. ${ }^{36}$ The Act, however, also states that a person who uses a UAS to "capture an image of an individual or privately owned real property" .. . "with the intent to conduct surveillance on the individual or property captured in the image" is guilty of a misdemeanor. ${ }^{37}$

Texas passed its law for the purpose of protecting "privacy as technology improves and the cost of surveillances goes down." ${ }^{38}$ In enacting its law, the Texas state legislature adopted a broad definition of image which includes "any capturing of sound waves, thermal, infrared, ultraviolet, visible light, or other electromagnetic waves, odor, or other conditions existing on or about real property in this state or an individual located on that property." 39 In addition, the legislature also set forth what constitutes lawful image capturing activities related to UAS operations. ${ }^{40}$

The State of Texas, mindful of the beneficial uses of UAS technology, included a statutory provision, which sets forth the type of image capturing activity by UAS which is permissible under state law. ${ }^{41}$ It is lawful to capture imagery using UAS for purposes such as:

32 VA. CODE ANN. $\S 15.2-836(2014)$.

33 FLA. STAT. $§ 934.50(2014)$.

34 Id. at $\$ 934.50(4)(\mathrm{b})(2014)$.

35 IND. CODE § 35-33-5-9 (2014); MonT. CODE ANN. § 46-5-109 (2013); see also Jol A. Silversmith, You Can't Regulate This: State Regulation of the Private Use of Unmanned Aircraft, 26 AIR \& SPACE LAW. 23, 23 (2013) (discussing whether state statutes regulating use of UAS by private parties are preempted by federal law).

36 See TEX. Gov. CODE $\S \S 423.001-.007$.

$37 I d$. at $\S 423.003$ (a)-(b). It should be noted that an affirmative defense is set forth under the statute if the individual who captured the image destroyed it (1) as soon as the person had knowledge that the image was captured in violation of this section; and (2) without disclosing, displaying, or distributing the image to a third party. TEX. GOV. CODE ANN. § 423.003(c) (West 2013).

38 Tex. House Research ORganization, House Bill ANAlysis, H.B. 912 at 5 (2013).

39 TEX. Gov. CODE ANN. § 423.001 (West 2013).

40 Id. at $\S 423.002$.

41 Id. at $\S 423.002$. 
1. Professional or scholarly research on behalf of a higher education institution; ${ }^{42}$

2. Airspace designated as a UAS test site or range authorized by the FAA; ${ }^{43}$

3. An operation, exercise, or mission of any branch of the United States military; ${ }^{44}$

4. Mapping; ${ }^{45}$ or

5. The property owner or legal tenant has consented to an image. ${ }^{46}$

A review of the exceptions allowing UAS to capture images also reveals the legislature's awareness about the benefits of this technology. The TPA specifically contains provisions allowing UAS to capture images on a property with the consent of the legal owner or tenant that benefits the agricultural community, an important part of the Texas economy. In 2012, the Texas agriculture industry generated more than $\$ 25.4$ billion in income. ${ }^{47}$

The TPA also grants law enforcement agencies, and in some cases other public and private entities, the right to utilize the image capturing technology in UAS for a number of reasons, such as:

1. Pursuant to a valid search or arrest warrant; ${ }^{48}$

2. In the immediate pursuit of a person law enforcement officers have reasonable suspicion or probable cause to suspect has committed a felony; ${ }^{49}$

3. Documenting a felony crime scene $;^{50}$

4. Investigating the scene of a human fatality; ${ }^{51}$

5. A motor vehicle accident causing death or serious bodily injury; ${ }^{52}$

6. Any motor vehicle accident on a state highway or federal interstate or highway; ${ }^{53}$

7. The search for a missing person; ${ }^{54}$

$42 I d$. at $\S 423.002(\mathrm{a})(1)(\mathrm{A})-(\mathrm{B})$.

43 Id. at $\S 423.002(\mathrm{a})(2)$.

44 Id. at $\S 423.002(\mathrm{a})(3)$.

$45 \quad I d$. at $\S 423.002(\mathrm{a})(4)$.

$46 \quad I d$. at $\S 423.002(\mathrm{a})(6)$.

47 Robert Holly, States Restrict Drone Use Because of Privacy Concerns, MIDWEST CENTER FOR INVESTIGATIVE REPORTING, (Jan. 29, 2015, 3:00 PM), http://investigatemidwest.org/2014/03/21/statesrestrict-drone-use-because-of-privacy-concerns/.

48 Tex. Gov. CODE ANN. § 423.002(a)(7) (West 2013).

$49 I d$. at $\S 423.002(\mathrm{a})(8)(\mathrm{A})$.

$50 I d$. at $\$ 423.002(\mathrm{a})(8)(\mathrm{B})$.

51 Id. at $\S 423.002(\mathrm{a})(8)(\mathrm{C})(\mathrm{i})$.

$52 I d$. at $\S 423.002(\mathrm{a})(8)(\mathrm{C})(\mathrm{ii})$.

$53 \quad I d$. at $\S 423.002(\mathrm{a})(8)(\mathrm{C})(\mathrm{iii})$.

54 Id. at $\S 423.002(\mathrm{a})(8)(\mathrm{D})$. 
8. Conducting a high-risk tactical operation that poses a threat to human life ${ }^{55}$

9. On private property that is open to the public and where the property owner consents to law enforcement safety responsibilities; ${ }^{56}$

10. Surveying the scene of a catastrophe or other damage to determine whether a state of emergency should be declared; ${ }^{57}$

11. Preserving public safety, protecting property, or surveying damage or contamination during a lawfully declared state of emergency; ${ }^{58}$

12. Conducting routine air quality sampling and monitoring, as provided by state or local law; ${ }^{59}$

13. At the scene of a spill, or a suspected spill, of hazardous materials; ${ }^{60}$

14. Fire suppression; ${ }^{61}$ or

15. Rescuing a person who is in imminent danger; ${ }^{62}$

The Texas legislature created a statute which enabled law enforcement agencies to utilize UAS technology for legitimate law enforcement uses. ${ }^{63}$ An argument could be made that some of the carved out exceptions are too narrow. For example, the legislature specifically allowed law enforcement agencies to use UAS for the purpose of capturing an image of someone who has allegedly committed a "misdemeanor or offenses punishable by a fine only." ${ }^{, 64}$ A legitimate question can be raised as to why the legislature did not allow for UAS to capture images of a suspect when a law enforcement has probable cause to believe that a suspect has committed a misdemeanor.

The TPA also requires the state Department of Public Safety to enact regulations for the use of UAS by law enforcement agencies. ${ }^{65}$ A review of the regulations reveals the important role that both the federal and state governments play in allowing UAS to be operated by local law enforcement agencies. Rule 1.143(b) requires UAS operators to comply with the Memorandum of Understanding entered into by the Texas Department of 
Public Safety and the FAA and U.S. Department of Justice. ${ }^{66}$ In addition, the Department's rules with respect to UAS operations requires law enforcement agencies to file reports with the FAA, including information such as unusual equipment malfunctions, operational/coordination issues, and pilot duty time per flight. ${ }^{67}$

In 2011, the City of Arlington Texas Police Department received approval from the FAA to operate two small UAS. ${ }^{68}$ Much work was undertaken by the local police department, even before the Texas Privacy Act was enacted in order to assure the public that the use of small UAS would enhance the quality of policing throughout the community. The department first developed a business case to acquire the technology and to prove its value for certain emergency situations. The department was interested in using small UAS for many types of operations including "crime scene investigations, especially those exposed to weather or with a large debris field" as well as searching for missing persons or fugitives. ${ }^{69}$

In order to educate the public about UAS and to address any concerns, the department held a series of public meetings to present information about the use of this technology to the public. ${ }^{70}$ The Chief of the Arlington Police Department gave a formal presentation to the city council. The council voted to approve the purchase and use of UAS by the Arlington Police Department. $^{71}$

The police department subsequently obtained a Certificate of Authorization (COA) to operate their UAS from the FAA. ${ }^{72}$ The department conducted a press briefing, which allowed the media to ask questions about the equipment and its intended use as well as to observe a flight. During that press briefing, the police department emphasized that it would not be using UAS for surveillance. ${ }^{73}$

\section{IDAHO'S UAS STATUTE}

Idaho enacted a law imposing UAS restrictions in $2013 .^{74}$ The statute specifically excludes UAS which are used for either "mapping or resource

6638 Tex. Reg. 7925 (Nov. 8, 2013). Local law enforcement agencies currently operate UAS pursuant to an FAA approved Certificate of Authorization (COA). Therefore, they are also bound by any conditions set forth in the COA.

67 TEX. DEPT. OF PUB. SAFETY, Unmanned Aircraft System Operations (Nov. 25, 2002), available at https://www.eff.org/document/texas-department-public-safety-unmanned-aircraft-regulations.

68 E-mail from Suzan Cogswell, Operations Analyst, Arlington Police Dept., to authors (Feb. 3, 2015, 8:14 PM) (on file with authors).

69 Id.

70 See id.

71 Id.

72 Id.

73 Id.

74 See IDAHO CODE ANN. § 21-213 (2013). 
management" from the definition of UAS. ${ }^{75}$ The statute also prohibits anyone from using UAS to photograph and publish an image of an individual without his or her consent. ${ }^{76}$ The statute also imposes strict conditions for the use of UAS by law enforcement agencies. The statute states in part:

(2)(a) Absent a warrant, and except for emergency response for safety, search and rescue or controlled substance investigations, no person, entity or state agency shall use an unmanned aircraft system to intentionally conduct surveillance of, gather evidence or collect information about, or photographically or electronically record specifically targeted persons or specifically targeted private property including, but not limited to:

(i) An individual or a dwelling owned by an individual and such dwelling's curtilage, without such individual's written consent;

(ii) A farm, dairy, ranch or other agricultural industry without the written consent of the owner of such farm, dairy, ranch or other agricultural industry. ${ }^{77}$

Idaho's law also allows for individuals to bring a cause of action against any private individual or public entity for violations of the prohibited conduct. ${ }^{78}$ The parties can recover monetary damages. ${ }^{79}$

Idaho, like many, if not most states, also has other laws that could be used to protect privacy rights. The state recognizes the four different tort claims which can be brought for invasion of privacy. ${ }^{80}$ This includes the claim of invasion of privacy by intrusion which is based "upon an intentional interference with the plaintiff's interest in solitude or seclusion, either as to his person or as to his private affairs or concerns." ${ }^{" 81}$

Idaho has a criminal trespass of privacy statute which states in part that "[i]t shall be unlawful for any person, upon the private property of another, to intentionally look, peer or peek in the door, window, or other transparent opening of any inhabited building or other structure located thereon, without visible or lawful purpose. ${ }^{, 82}$ It is unclear whether the legislature, in enacting the statute, intended for the phrase "upon the private property of another" to mean that the perpetrator has to physically be on the property of another in order for it to constitute a trespass. A person could use UAS to enter upon the private property of another to intentionally peek in the window without lawful purpose. In that case, one could argue that such an action constitutes

75 Id. at $\S 21-213(1)(\mathrm{a})-(1)(\mathrm{b})(\mathrm{ii})$.

$76 I d$. at $\S 21-213(2)(\mathrm{b})$.

77 Id. at $\$ 21-213(2)(\mathrm{a})$.

78 Id. at $\S 21-213(3)(\mathrm{a})$.

79 Id. at $\S 21-213(3)(\mathrm{b})$.

80 Jensen v. State, 72 P.3d 897, 902 (2003).

81 Uranga v. Federated Pubs., Inc., 67 P.3d 29, 32 (2003) (citing Hoskins v. Howard, 971 P.2d 1135 (1999)).

82 IDAHO CODE ANN. $§ 18-7006$ (2013). 
a violation of Idaho's trespass of privacy statute. ${ }^{83}$

In enacting its statute, the Idaho legislature specifically exempted UAS operations used for "mapping or resource management" from the statutory definition of UAS. ${ }^{84}$ Idaho's agriculture sector is large. In 2014, Idaho's farmers generated $\$ 9.7$ billion in sales. ${ }^{85}$ Idaho is the largest grower of potatoes in the United States. ${ }^{86}$ Dairy and cattle production are growing sectors of the state economy. ${ }^{87}$

Incorporating UAS technology into farming has many benefits. UAS can be used locate lost cattle. ${ }^{88}$ The technology can also be used to detect stress in crops, even before it becomes detectable to the naked eye. ${ }^{89}$ In early 2015, Empire Unmanned, LLC received an exemption from the FAA in order to provide commercial UAS services to farmers and the broader agricultural industry. ${ }^{90}$ The use of UAS to monitor crops could increase the value by ten U.S. dollars per acre. ${ }^{91}$

Idaho appears to have been successful in using its police power to enact a law limiting the use of UAS by law enforcement and protecting the privacy rights of its citizens. Moreover, the legislation effectively promotes the use of UAS for agricultural uses by removing any governmental restrictions. It will be interesting to see whether the needs of public or private sector entities requiring UAS will result in the legislature taking action to amend the Idaho UAS statute.

83 See Villasenor, supra note 13, at 499-500 (2013) (discussing other states' trespass statutes and possible violations by UAS).

84 IDAHO CODE ANN. § 21-213(1)(b)(i) (2013).

85 Zach Kyle, 2014 Was Bumper Year for Idaho Agriculture, IDAHO STATESMAN, Feb. 1, 2015, http://www.idahostatesman.com/2015/02/01/3622252_2014bumper-year-for-idahoagriculture.html?rh= 1.

86 Alena Bosse \& Michael Boland, Kansas State University, revised April 2014 by Shannon Hoyle, AgMrC, Iowa State University, Agricultural Marketing Res. Ctr, Potato Profile, http:// www.agmrc.org/commodities_products/vegetables/potato-profile/ (last visited Feb. 10, 2015).

87 Kyle, supra note 85.

88 Willie Vogt, Drone Excitement Not Abating, FARM InDUS. NEWS (Jan. 22, 2015), available at PROQUEST DOCUMENT ID 1647594367.

89 John O'Connell, Idaho Drone Project Studies Potato Stress, CAPITAL Press (May 27, 2014), http://www.capitalpress.com/Idaho/20140527/idaho-drone-project-studies-potato-stress.

90 Matthew Weaver, Idaho Drone Company First to Receive Ag Exemption, CAPITAL PRESS (Jan. 15, 2015), http://www.capitalpress.com/Business/20150112/idaho-drone-company-first-to-receive-agexemption. Until regulations are enacted by the FAA, entities wishing to operate UAS are required to obtain an exemption from the FAA. The FRMA "grants the Secretary of Transportation the authority to determine whether an airworthiness certificate is required for a UAS to operate safely in the National Airspace System (NAS)." The authority is being executed on a case-by-case basis for UAS operators to perform commercial operations prior to the finalization of the Small UAS Rule. See FAA, UNMANNED AIRCRAFT SYSTEMS SECTION 333 (Feb. 8, 2015), available at https://www.faa.gov/uas/ legislative_programs/section_333/.

91 Weaver, supra note 90. 


\section{LOCAL GOVERNMENT REGULATION OF UAS}

Action has also taken place at the local government level in order to address UAS operations. In February 2013, Charlottesville Virginia became the first local government to take action on UAS by imposing a two-year moratorium. ${ }^{92}$ The action was similar to that taken by the Virginia General Assembly that same year.

The City of Evanston Illinois passed a resolution in May 2013, which, subject to a few exceptions, also established a moratorium on the use of UAS for two years. ${ }^{93}$ The language in the resolution called on both the state and federal government to enact regulations pertaining to the use of drone technology. ${ }^{94}$ The legal effect of a resolution is to express a policy preference by the City Council, as opposed to a law, which can be enforced. In 2013, the State of Illinois enacted a set of laws that restricted the use of UAS by law enforcement agencies in the state. ${ }^{95}$

The City of St. Bonifacius, Minnesota, passed a resolution and an ordinance in 2013 imposing a ban on UAS, with limited exceptions for both private users as well as law enforcement agencies. ${ }^{96}$ The ordinance language is quite broad in that it prohibits use of UAS "within the air space of the City." 97 To date, the State of Minnesota has not passed a law regulating UAS.

The State of Pennsylvania has not enacted a law dealing with UAS. The Township of Conoy, Pennsylvania sought to address a growing concern in the community about UAS. In March 2013, the Township passed a nuisance ordinance, which contains a provision regulating the use of UAS and remote controlled aircraft. ${ }^{98}$ Section 2(f) of the ordinance prohibits parties from conducting acts on private or public property that constitute nuisances in fact including " $[\mathrm{t}]$ he operation of remote controlled or other non-tethered aircraft over property not owned by the operator and without the permission of the property owner." 99 The Township's ordinance defines nuisance as "the unreasonable, unwarrantable, or unlawful use of public or private property which causes injury, damage, hurt, inconvenience, annoyance or discomfort to any person or resident in the legitimate enjoyment of his reasonable rights of a person or property." 100

92

93

94

95

96

97

98 Conoy Twp., Pa. Ordinance No. 1-13-14 §2(f) (Mar. 14, 2013), available at http://

www.conoytownship.org/files/2013/12/1-3-14-2013_Nuisance_Ordinance.pdf.

99 Id.

100 Id.

Charlottesville, VA Anti-Drone Resolution (Feb. 4, 2013).

EVANSTON, IL., RES. 27-R-13, § 2 (2013).

Id. at $\S 3$.

725 ILl. COMP. Stat. ANN. 167/10 (LexisNexis 2014).

City OF ST. BONIFACIUS, ORD. NO. 115, § 9-9.3-9.4 (2013).

d. at $\S 9-9.3$.

d. 
Instead of addressing concerns about privacy, the Township Board appeared to have been concerned with ensuring that property owners are not adversely impacted by UAS in the enjoyment of their property. After the ordinance was enacted, Conoy Township's solicitor stated that the enactment of the law had "nothing to do with privacy. This has to do with people who are or may be disturbed in the enjoyment of their property through the flying of remote-controlled or non-tethered aircraft."

Conoy Township's approach to addressing potential problems with UAS is quite different from Texas and Idaho. The ordinance does not address any image capturing activity in its ordinance. ${ }^{102}$ Instead, it imposes a broad ban on flying UAS without permission over another person's property. It would be difficult for a party to argue that the use and enjoyment of their property is affected by a UAS flying somewhere near their property. UAS generate very little or no noise. Unless they are operating at a lower altitude, it may be difficult for a property owner to detect the presence of UAS over their property. One could also argue that the ordinance violates the overbreadth doctrine and consequently inhibits important First Amendment rights of media outlets who may want to use UAS to collect images for important stories in the Township. ${ }^{103}$

Conoy Township's ordinance could also be problematic from a preemption standpoint. The federal government has exclusive sovereignty over the airspace of the United States. ${ }^{104}$ It has been noted that the "FAA can and does promulgate regulations that control the air all the way down to the ground, even over private property." 105 The federal government has the exclusive power to do this. Local governments are preempted from enacting ordinances that impose restrictions on the use of airspace.

The U.S. Supreme Court, in United States v. Causby, addressed the issue regarding "who owns the airspace above private property." 106 In that case, the property owners brought an action against the U.S. government claiming that military flights which departed or arrived at the nearby airport were operating so low so as to constitute a taking in violation of the Fifth

101 Chad Umble, Conoy Township Passes Ordinance that Limits Drones' Air Space, LANCASTERONLINE (Mar. 14, 2013), http://lancasteronline.com/news/conoy-township-passesordinance-that-limits-drones-air-space/article_c975a727-24b0-5b35-bc60-cd14c31341b4.html.

102 Conoy Twp., Pa. Ord. No. 1-13-14 §2(f) (Mar. 14, 2013), available at http:// www.conoytownship.org/files/2013/12/1-3-14-2013_Nuisance_Ordinance.pdf.

103 See City of Chicago v. Morales, 527 U.S. 41, 52 (1999).

10449 U.S.C. $\S 40103(\mathrm{a})(1)$. There are also Federal Aviation Regulations which set minimum altitudes for safe flight. See Villasenor, supra note 13, at 489-91 (discussing that some categories of UAS are currently subject to FAA imposed altitude maximums).

105 Id. at 491.

106 Congressional Research Service, Integration of Drones into Domestic Airspace: Selected Legal Issues, at 6 (2013) (citing United States. v. Causby, 328 U.S. 256 (1946)). 
Amendment of the U.S. Constitution. ${ }^{107}$ The plaintiff operated a chicken farm which was adversely impacted by the aircraft noise. ${ }^{108}$

In stating that the "airspace is a public highway," the Court noted that in order for a property owner "to have full enjoyment of the land, he must have exclusive control of the immediate reaches of the enveloping atmosphere." 109 Subsequent cases have "clearly established that overhead flights leading to impairment of the owner's livelihood or that cause physical damage qualify as an interference with use and enjoyment of property." 110

The Conoy Township's nuisance ordinance prohibiting the use of UAS - unless it occurs on the operator's own property, or with the property owner's permission, may be problematic once a final rule is enacted by the FAA. Court challenges may be brought to determine the legal authority of local governments to regulate nuisance activity versus the broad authority of the FAA to regulate airspace activity. Even if a court were to rule against a local government, the role of states and local governments to use their police powers to regulate privacy issues related to UAS operations may be upheld. ${ }^{111}$

\section{CONCLUSION: STATES AND LOCAL GOVERNMENTS SHOULD PLAY IMPORTANT ROLES IN REGULATING AREAS SUCH AS PRIVACY THAT PROTECT THE PUBLIC AND UAS OPERATORS}

One commentator has suggested that a federal or state consumer protection law be enacted that sets forth permissible uses of UAS "in domestic airspace both law enforcement agencies and private parties." ${ }^{.12}$ The law would address data collection and surveillance specifically undertaken by UAS and would ensure that both public and private entities do not use UAS in a manner that violates an individual's privacy. ${ }^{113}$

While this solution is commendable, in practice, it may create some of the same legal problems that exist today. The statutory and subsequent interpretation of those laws has established a strong legal basis for the notion that the federal government has exclusive authority to regulate UAS operations. ${ }^{114}$ Furthermore, the FAA has not played a role in addressing or enacting rules that affect privacy rights in the context of aviation

107 Causby, 328 U.S. at 258-61.

108 Id.

109 Id. at 264.

110 Integration of Drones into Domestic Airspace: Selected Legal Issues, supra note 106, at 10.

111 See id.

112 Chris Schlag, The New Privacy Battle: How the Expanding Use of Drones Continues to Erode Our Concept of Privacy and Privacy Rights, 13 PITT. J. TECH. L. \& POL'Y 1, 21 (2013).

113 Id.

114 City of Burbank v. Lockheed Air Terminal, Inc., 411 U.S. 624, 639 (1973). 
operations. ${ }^{115}$ The agency has publicly endorsed the notion that state laws should be used to protect privacy rights. ${ }^{116}$

States like Texas, Idaho, and Virginia have followed suit with enacting statutes that address the use of UAS by law enforcement as well as restricting UAS use by private individuals. ${ }^{117}$ In dealing with issues pertaining to the use of UAS for surveillance purposes, the federal government already has a wiretap statute. ${ }^{118}$ Congress could amend the law to apply to UAS. ${ }^{119}$ States, however, could also choose to enact their own laws in this area. ${ }^{120}$

There are also areas of law where states will have to lead the way. UAS will certainly be used to engage in protected First Amendment activities such as news and information gathering. States should be allowed to experiment with legislative solutions that allow UAS to be used for information gathering while also protecting the privacy rights of individuals. ${ }^{121}$

There are other areas concerning privacy rights that will continue to evolve exclusively in the state legislatures. Privacy tort laws "govern the way private information is obtained and used." " 222 tate privacy laws have traditionally regulated private audio and video recording. ${ }^{123}$ States can often serve as laboratories for novel solutions to complex problems without putting the entire country at risk for a failed solution. ${ }^{124}$ This is especially true as lawmakers try to strike the right balance in terms of understanding the technology and the important benefits of UAS to society with the privacy concerns of their fellow citizens.

115 FAA, INTEGRATION OF CiVIL UNMANNED AIRCRAFT SYSTEMS (UAS) IN THE NATIONAL AIRSPACE SYSTEM (NAS) ROADMAP (2013), available at https://www.faa.gov/uas/legislative_programs/ uas_roadmap/media/UAS_Roadmap_2013.pdf. Other agencies like the Transportation Security Administration do address privacy issues, especially in the context of air passenger screening equipment, FAA Modernization and Reform Act of $2012 \S 826$ (c), H.R. 658, 112th Cong. (2012).

116 FAA, INTEGRATION OF CIVIL UNMANNED Aircraft SYSTEMS (UAS) IN THE NATIONAL AIRSPACE SYSTEM (NAS) ROADMAP (2013), available at https://www.faa.gov/uas/legislative_programs/ uas_roadmap/media/UAS_Roadmap_2013.pdf.

117 Margot A. Kaminski, Drone Federalism: Civilian Drones and the Things They Carry, 4 CALIF.

L. REV 57 (2013).

118 Id. at 58.

119 Id.

120 Id. (stating that the updated federal statute could provide the floor for state regulation of law enforcement UAS use).

121 Id. at 63-64.

122 Id. at 65.

123 Id.

124 James A. Gardner, The "States-as-Laboratories" Metaphor in State Constitutional Law, 30 VAL. U. L. REV. 475, 476 (1996). 